\title{
PENERAPAN FLIPPED LEARNING DENGAN MEDIA VIDEO PADA FIQIH KELAS XII IPA 1 DI MA BAHRUL ULUM BLAWI
}

\author{
Very Misbahul Munir, Abdulloh Hamid \\ UIN Sunan Ampel Surabaya, Jawa Timur, Indonesia \\ e-mail: Very_chayoo@yahoo.co.id, doelhamid@uinsby.ac.id
}

\begin{abstract}
Abstrak
Dalam beberapa kasus, materi fiqih kurang terakomodasi dengan baik di kelas, kondisi ini berdampak pada penurunan hasil kerja siswa, dan jika berpijak dari hasil pengamatan sebelumnya terlihat siswa kurang bahkan tidak antusias terhadap pertanyaan-pertanyaan yang diajukan guru di akhir-akhir pembelajaran. Tujuan dari penelitian ini adalah untuk meningkatkan aktivitas dan hasil belajar siswa pada mata pelajaran Fiqih bab Pernikahan di MA Bahrul Ulum Blawi dengan diterapkannya model pembelajaran berbasis flipped learning. Penelitian ini dilaksanakan dengan menggunakan metode semi Penelitian Tindakan Kelas (PTK) yang dilaksanakan sebanyak satu siklus. Peneliti mengumpulkan data melalui dokumentasi, observasi, catatan lapangan dan tes. Berdasarkan hasil temuan lapangan, pada observasi pada pertemuan pertama, siswa yang aktif untuk menjawab pertanyaan dan menyampaikan pendapat hanya beberapa siswa saja, terutama yang ada di barisan depan. setelah dilaksanakan atau diterapkan model pembelajaran berbasis flipped learning, banyak siswa yang aktif turut serta dalam diskusi pro dan kontra dalam masalah hukum fiqih pada video pelaksanaan akad nikah melalui via telepon /online.
\end{abstract}

Kata kunci : Flipped Learning, Media Video, Fiqih Nikah

\section{PENDAHULUAN}

Fiqih Muamalah tersusun dari dua kata yaitu fiqih dan Muamalah. ${ }^{1}$ Fiqih secara bahasa memiliki makna pengertian atau pemahaman. Fiqih merupakan sekumpulan pembahasan yang telah dirumuskan oleh para ulama' dengan metode yang sangat ketat dari dalil-dalil naqliyyah maupun aqliyah. Di dalamnya termuat pembahasan yang sangat detail terkait kandungan dalil-dalil tersebut dan konsekwensinya. Abdul Wahab Khallaf mendefinisikan fiqih dengan pengetahuan tentang hukum-hukum syara mengenai perbuatan manusia yang diusahakan dari dalil-dalil yang terinci atau kumpulan hukum syara mengenai perbuatan manusia yang diperoleh dari dalil-dalil yang terinci. ${ }^{2}$ Hal itulah yang menyebabkan fiqih menjadi sangat

\footnotetext{
1068

${ }^{2}$ Abd. Wahab khalaf, Ilm Ushul al-fiqh (Jakarta: al-majlis al-a'la al-indunisi, 1972), h. 11.
}

${ }^{1}$ Ahmad Warson Munawwir, Kamus Arab -Indonesia Terlengkap (Surabaya: Pustaka Progresif, 1997), h.

Al Qalam: Jurnal Ilmiah Keagamaan dan Kemasyarakatan

Vol. 14, No. 2, Juli-Desember 2020 
penting karena fiqih merupakan penjabaran dari beberapa dalil-dalil yang masih bersifat umum dan universal.

Lafadz yang kedua ( المعاملة), secara bahasa adalah kepentingan. ${ }^{3}$ Menurut istilah yang dimaksud mu`amalah adalah bagian fiqih selain ibadah yaitu hukum-hukum yang mengatur hubungan interpersonal antar manusia ${ }^{4}$. Mu'amalah menurut golongan Syafi'i adalah bagian fiqih untuk urusan-urusan keduniaan selain perkawinan dan hukuman, yaitu hukum-hukum yang mengatur hubungan manusia dengan sesama manusia dan alam sekitarnya untuk memperoleh kebutuhan hidupnya. Menurut Ibnu Abidin, muamalah meliputi lima hal, yakni:1) Transaksi kebendaan (Al-Mu`awadlatul maliyah), 2. Pemberian kepercayaan (Amanat), 3) Perkawinan (Munakahat), 4). Urusan Persengketaan (Gugatan dan peradilan), 5). Pembagian warisan ${ }^{5}$. Fiqih juga bisa disebut sebagai ilmu social yang bersifat dinamis, karena fiqih tidak hanya dikenal aspek ubudiyyah vertikal semata, namun aspek sosial horisontal (muamalah) juga menjadi obyek pembahasan yang sangat panjang.

Drs. Masduha Abdurrahman dalam bukunya Pengantar dan Asas-asas Hukum Perdata Islam (Fiqih Muamalah) adalah muamalah yang memiliki arti khusus, yaitu bagian fiqih yang membahas hukum-hukum yang berkaitan dengan perbuatan dan perhubungan manusia sesama manusia dalam urusan kebendaan dan hak-hak kebendaan serta cara-cara menyelesaikan persengketaan mereka. Dapat diambil sebuah kesimpulan bahwa secara garis besar definisi atau pengertian fiqih muamalah yaitu, hukum-hukum yang berkaitan dengan tata cara berhubungan antar sesama manusia, baik hubungan tersebut bersifat kebendaan maupun dalam bentuk perjanjian perikatan. Fiqih mu'malah adalah salah satu pembagian lapangan pembahasan fiqih selain yang berkaitan dengan ibadah, artinya lapangan pembahsan hukum fiqih mu'amalah adalah hubungan antar sesama manusia, bukan hubungan vertikal manusia dengan tuhannya.

Pengetahuan tentang ilmu fiqih ditarik dalam dunia pendidikan formal di madrasah menjadi kesatuan kurikulum yaitu mata pelajaran Fiqih. Mata pelajaran Fiqih adalah salah satu bagian dari Pendidikan Agama Islam (PAI) yang mempelajari tentang fiqih ibadah, terutama menyangkut pengenalan dan pemahaman cara-cara pelaksanaan rukun islam mulai dari ketentuan dan tata cara serta ketentuan tentang makanan dan minuman, khitan, kurban, dan pelaksanaan jual beli, pinjam meminjam, dan muamalah lainnya termasuk pernikahan. Mata pelajaran fiqih dalam kurikulum Madrasah Aliyah adalah salah satu bagian mata pelajaran agama islam yang diarahkan untuk menyiapkan peserta didik agar mampu mengenal, memahami, menghayati, dan mengamalkan hukum islam, yang kemudian menjadi dasar pandangan hidupnya (way of life) melalui kegiatan, bimbingan, pengajaran, latihan, penggunaan pengamalan dan pembiasaan. Mata pelajaran Fiqih Madrasah Aliyah ini meliputi: Fiqih Ibadah, Fiqih Muamalah, Fiqih Munakahat, Fiqih Jinayat, Fiqih Siyasah, dan Ushul Fiqhi. Hal ini menggambarkan bahwa ruang lingkupnya mencakup

\footnotetext{
${ }^{3}$ Munawwir, Kamus Arab -Indonesia., h. 974

${ }^{4}$ Abdurrahman, Pengantar dan Asas-Asas Hukum Perdata Islam., h. 31

${ }^{5}$ Ibid, h. 28
} 
perwujudan keserasian, keselarasan, dan keseimbangan sesama manusia, makhluk lainnya, maupun lingkungannya (Hablun min Allah wa Hablum Min Al Nās).

Namun dalam kenyataannya materi fiqih kurang terakomodasi dengan baik di kelas, kondisi ini berpengaruh pada hasil kerja siswa menjadi rendah dan berdasarkan pengamatan sebelumnya terlihat siswa kurang bahkan tidak antusias terhadap pertanyaan-pertanyaan yang diajukan guru di akhir-akhir pembelajaran. Terbukti pada nilai akhir Ujian Tengah Semester pada semester lalu, hampir separuh dari 24 penduduk kelas XII IPA 1 MA Bahrul Ulum Blawi nilainya kurang dari standar KKM. Dan ini merupakan masalah.

Mengenali unsur dari psikologi belajar siswa terlebih dahulu, dikenal dengan gejala jiwa kognisi, kognisi atau kognitif berasal dari kata cognition yang padanan katanya knowing, berarti mengetahui. Dalam arti luas, cognition (kognisi) ialah perolehan, penataan, dan penggunaan pengetahuan. ${ }^{6}$ Proses perkembangan kognisi siswa ataupun individu meliputi, pertama, Pengamatan merupakan proses belajar mengenal segala sesuatu yang ada di sekitar kita dengan menggunakan alat indera kita Kedua, Tanggapan sebagai salah satu fungsi jiwa yang pokok, dapat diartikan sebagai gambaran ingatan dari pengamatan, ketika objek yang diamati tidak lagi berada dalam ruang dan waktu pengamatan. Jadi, jika proses pengamatan sudah berhenti, dan hanya tinggal kesan-kesannya saja, peristiwa demikian ini disebut tanggapan. ${ }^{7}$ Ketiga, Fantasi adalah daya jiwa untuk membentuk atau mencipta tanggapan-tanggapan baru dengan bantuan tanggapan yang sudah ada. Keempat, Daya Ingatan, Ingatan (memory) ialah kekuatan jiwa untuk menerima, menyimpan, dan mereproduksi kesan-kesan. Kelima, Proses menerima, menyimpan, dan mengolah kembali informasi, (baik informasi yang didapat lewat pendengaran, penglihatan atau penciuman) biasa disebut "berfikir". Berfikir adalah media untuk menambah perbendaharaan/khazanah otak manusia yang menghubungkan pengertian satu dengan pengertian lainnya dalam rangka mendapatkan pemecahan persoalan yang dihadapi. Dalam pemecahan persoalan, individu membeda-bedakan, mempersatukan dan berusaha menjawab pertanyaan, mengapa, untuk apa, bagaimana, dimana dan lain sebagainya. Keenam, Intelligensi ialah kesanggupan rohani untuk menyesuaikan diri kepada situasi yang baru dengan menggunakan berfikir menurut tujuannya. Kapankah seseorang dikatakan berbuat intelligen? Seseorang dapat dikatakan berbuat intelligen kalau dalam situasi tertentu, ia dapat berbuat dengan cara-cara yang tepat. Artinya, ia dapat memecahkan kesulitankesulitan, soal-soal yang terdapat dalam situasi itu. Dengan kata lain, ia dapat menyesuaikan diri dengan situasi yang baru. ${ }^{8}$

Selain itu, faktor yang kurang mendukung kegiatan pembelajaran adalah kurangnya kesiapan siswa. Menurut Jameis Drever dalam Slameto salah satu faktor yang mempengaruhi siswa dalam belajar adalah kesiapan atau readiness. Kesiapan yang dimiliki dalam pembelajaran akan membuat siswa memberikan

\footnotetext{
${ }^{6}$ Muhibbin Syah, "psikologi belajar", (jakarta: rajawali press, 2009) h. 22

7 M.Ishom Ahmadi, "ya ayyatuha an nafsu al muthmainnah". (yogyakarta: sj press, 2009) h. 26-27

${ }^{8}$ ibid, h. 70-91
} 
suatu respon atau reaksi atas informasi yang diterimanya. Jika siswa memasuki kelas tanpa membawa persiapan, maka siswa akan pasif, cenderung cepat bosan, dan tidak memperhatikan penyampaian materi oleh guru. Bahkan tidak jarang mereka tidur di kelas. ${ }^{9}$

Teori di atas sejalan dengan teori tentang komunikasi pembelajaran. dalam Zainiyati. Keenam gejala kognisi siswa di atas saling berkaitan dengan system pengelolaan informasi. Pengelolaan informasi atau dinamakan interpersonal adalah proses pengelolaan infformasi oleh seseorang ketika orang tersebut menerima stimulus atau rangsangan dari luar. ${ }^{10}$ Persiapan belajar oleh siswa sebelum memulai pembelajaran di kelas yang dirancang dalam pembelajaran flipped learning menjadi sejalan dengan kedua teori tersebut. Stimulus yang baik, difasilitasi dengan media yang tepat, melahirkan suatu system penyampaian informasi yang baik, sehingga melahirkan pesan dan kesan yang melekat dalam ingatan siswa sebagai bekal awal sebelum mengikuti pembelajaran di kelas. Berbekalkan pengetahuan menarik nilai positif dalam kelas, menjadikan siswa lebih aktif yang selanjutnya menjadikan kelas terasa lebih hidup.

Kelas terbalik, populer dengan Flipped learning atau Flipped Classroom adalah model pembelajaran yang membalik model pembelajaran tradisional, dimana materi diberikan melalui media video atau audio untuk depelajari secara mandiri di rumah, sebagai bahan untuk berdiskusi di kelas pada pertemuan mendatang. Kelas berbalik (Flipped instruction) dikenal juga sebagai Flipped classroom atau Flipped Learning yaitu membalikkan penerimaan dan penggunaan materi di kelas tradisional dengan menggunakan waktu di kelas untuk mengklarifikasi pertanyaan dari memberi materi baru. ${ }^{11}$

Penelitian ini bertujuan untuk mengatasi masalah belajar siswa tetapi tidak keseluruhan. Tidak termasuk guru yang cenderung mengajar dengan metode ceramah (konvensional) yang pernah diamati oeleh peneliti pada beberapa pertemuan sebelumnya sebelum peneliti menerapkan model pembelajaran berbasis flipped learning. Melalui penelitian ini akan diketahui 1) bagaimana penerapan model pembelajaran berbasis flipped learning pada mata pelajaran fiqih di kelas XII IPA 1 MA Bahrul Ulum Blawi, 2) Apakah penerapan model pembelajaran berbasis flipped learning pada mata pelajaran fiqih di kelas XII IPA 1 MA Bahrul Ulum Blawi mampu meningkatkan aktivitas belajar siswa, 3) apakah penerapan model pembelajaran berbasis flipped learning pada mata pelajaran fiqih di kelas XII IPA 1 MA Bahrul Ulum Blawi mampu meningkatkan hasil belajar siswa. Sehingga akan memberikan manfaat bagi 1) Guru, sebagai pertimbangan model pembelajaran dalam mata pelajaran fiqih dikelas untuk mengatasi masalah rendahnya aktivitas dan hasil

\footnotetext{
${ }^{9}$ Slameto, Belajar Dan Faktor-Faktor Yang Mempengaruhinya, (Jakarta: Rineka Cipta, 2003), h.16

${ }^{10}$ husniyatus Salamah Zainiyati, pengembangan media pembelajaran berbasis ict, (Jakarta: Kencana, 2017)

11 Sri Utami, Pengaruh Model Pembelajaran Flipped Classroom Tipe Peer Instruction Flipped Terhadap Kemampuan Pemecahan Masalah Matematik Siswa; Penelitian Quasi Eksperimen di Kelas XI SMA Negeri 1 Parung), SkripsI. Jakarta: FTK UIN Syarif Hidayatullah, h, 16
} 
belajar siswa; 2) Peneliti, Dapat digunakan sebagai pengalaman dalam merancang model pembelajaran flipped classroom untuk memecahkan masalah pembelajaran dikelas, khususnya rendahnya aktivitas dan hasil belajar siswa; 3) Peneliti selanjutnya, sebagai referensi dan bahan pertimbangan untuk melakukan kegiatan penelitian mengenai penerapan model pembelajaran flipped classroom untuk meningkatkan aktivitas dan hasil belajar siswa dikemudian hari.

\section{METODE PENELITIAN}

Penerapan model pembelajaran berbasis flipped learning pada mata pelajaran fiqih di kelas XII IPA 1 MA Bahrul Ulum Blawi ini sepenuhnya dilakukan oleh peneliti dengan jumlah subyek 24 siswa yang separuhnya mendapatkan nilai rendah di bawah KKM, yaitu 75. Fokus penelitian pada mapel Fiqih adalah materi tentang Pernikahan dalam Islam dengan kompetensi dasar 1) Memahami ketentuan pernikahan dalam Islam. 2) Memperagakan tata cara pernikahan dalam Islam.

Penelitian ini berbasis semi PTK, penelitian tindakan kelas. Sebelum melaksanakan tindakan, peneliti memantau pelaksanaan pembelajaran pada minggu sebelumnya yang dilaksanakan oleh guru mata pelajaran. Pertemuan selanjutnya kelas pembelajaran dipegang oleh peneliti dengan melaksanakan kompetensi dasar yang pertama, yaitu memahami ketentuan pernikahan dalam Islam dengan metode ceramah dan diakhir inti pembelajaran guru menampilkan video akad nikah. Pada akhir pembelajaran peneliti melaksakan refleksi tentang bagaimana pendapat siswa setelah ditampilkan video tersebut.

Sebelum pembelajaran berakhir peneliti membagikan file berupa video akad nikah yang dilaksanakan via telepon/ online, beserta linknya (Youtube), membagi anggota kelas menjadi dua kelompok, yaitu kelompk pro dan kontra. Dan peneliti membagikan lembar kuesioner untuk menilai pembelajaran KD pertama.

\section{HASIL DAN PEMBAHASAN}

Scope dan Issue yang diketengahkan terkait dengan kajian-kajian umum dan yang berorientasi kepada membangun paradigma masyarakat yang lebih maju. Jenis penelitian bisa berupa kajian literatur, kualitatif, kuantitaif maupun mixed method.

Penerapana model pembelajaran berbasis flipped learning pada kelas XII IPA I MA. Bahrul Ulum Blawi hanya dilaksanakan satu siklus saja, pre dan post class yang masih jauh dari kesempurnaan karena banyak sekali faktor yang mendominasi sehingga penerapan model pembelajaran berbasis flipped learning tidak berjalan dengan maksimal, diantaranya hanya bisa dilaksanakan dalam satu siklus, yaitu terhitung dua kali pertemuan.

Berdasarkan konsep model pembelajaran flipped learning yang telah disampaikan oleh Bergmann and Sams (2012) bahwa ketika pembelajaran yang seperti biasa dilakukan di kelas dilakukan oleh siswa di rumah, dan pekerjaan rumah yang biasa dikerjakan di rumah diselesaikan di sekolah. Pada penelitian ini siswa telah mempelajari materi di kelas dan di rumah sebagai perbandingan. Sedangkan tugas yang biasanya 
dikerjakan di rumah pada penelitian ini dikerjakan di kelas melalui kegiatan diskusi kelompok dan diskusi kelas

Merujuk pada model pembelajaran dalam Barry Moris membagi pembelajaran menjadi empat tipe. Keempat tipe tersebut berubah sesuai dengan perkembangan media baik berupa software maupun hardware. Hal ini membuktikan adanya pergeseran peran sebagai penyampai pesan atau materi pelajaran. ${ }^{12}$ Penelitian yang dilaksanakan peneliti ini dilaksanakan dengan model kedua yaitu, Tipe II (Pola Pembelajaran Tradisional II), adalah tipe pembelajaran konvensional yang sudah bermedia. Tapi masih didominasi oleh guru saja. Siswa hanya sebagai penerima. Dilaksanakan satu arah, peneliti menjelaskan materi tentang ketentuan pernikahan dalam Islam dengan metode ceramah kemudian menampilkan video pelaksanaan akad nikah sebagaimana umumnya. Peneliti menanyakan bagaimana pendapat siswa tentang tampilan akad nikah tersebut. Sebagiamana hasil pengamatan peneliti jumlah siswa yang menanggapi pertanyaan sangat sedikit, hanya siswa yang ada di barisan depan dan memang aktif di kelas.

Sebagaimana rute pelaksanaan penelitian ini, peneliti membagikan lembar kuesioner, yang berisi tentang pertanyaan seputar penilaian terhadap pembelajaran yang dilaksanakan peneliti. Sebagian siwa merasa nyaman dengan pembelajaran pada hari itu juga oleh peneliti. Diantara alasan yang dikemukakan siswa merasa bosan dengan gurunya. Menanggapi pada pelaksanaan pemberian video pelaksanaan akad nikah, siswa yang aktif hanya beberapa, siswa tidak menanggapi pertanyaan seputar pendapat tentang video tersebut dikarenakan siswa merasa belum waktunya untuk membahas bab tersebut.

Sehingga dapat disimpulkan bahwa pembelajaran yang masih bersifat konvensional sekalipun menggunakan media, jika masih teacher oriented maka kelas tidak akan hidup ketika diberikan umpan balik berupa penanggapan. Sekalipun mereka merasa nyaman dengan penyampaian peneliti saat menjelaskan materi.

Pada pertemuan kedua, Kegiatan di dalam kelas sepenuhnya diisi dengan kegiatan diskusi yang menuntut partisipasi siswa dalam membentuk pengetahuan yang sempurna, maka keberadaan guru di dalam kelas hanya sebagai fasilitator. Hal tersebut sesuai dengan The Flipped Learnung Network \& Pearsons School Achievemeny Service dalam Hamdan dan Mc. Knight ${ }^{13}$ bahwa salah satu pilar utama model pembelajaran flipped learning adalah model pembelajaran yang berpusat pada guru berganti menjadi pembelajaran berpusat pada siswa, sehingga siswa lebih aktif terlibat dalam pembentukan pengetahuannya.

Men-flipp pembelajaran, siswa yang sebelumnya disuguhi video pelaksanaan akad nikah pada pertemuan pertama, dengan memberikan video akad nikah yang dilaksanakan melalui via telepon / online.

\footnotetext{
${ }^{12}$ Rusman, dkk, 2013. Pembelajaran Berbasis TIK, Jakarta: Rajawali Pers., h. 43-44.

${ }^{13}$ Arfiyanti Agustiningrum \& Agung Haryono, "Penerapan Model Pembelajaran Flipped Classroom Dan Course Review Horay Berbasis Lesson Study Untuk Meningkatkan Aktivitas Dan Hasil Belajar Siswa Pada Mata Pelajaran Ekonomi di kelas XI IPS 2 MAN Kota Batu, JFE-Vol. 10 No. 2 2017, h. 150.
} 
Berdasarkan pengamatan peneliti,siswa lebih antusias. Salah satu siswa dalam lembar kritik dan saran yang dibagikan oleh peneliti mengemukakan bahwa:

"Pak, saya sangat suka dengan pembelajaran kali ini. Apalagi kasus dalam pernikahan ini ternyata ada di kehidupan nyata, dan saya belum pernah menemuinya di sekitar saya" 14

Selain alasan di atas, peneliti juga menemukan antusias siswa yang sangat bagus, dibandingkan pertemuan pertama, yang mana tidak memiliki kesiapan. Siswa yang didesain dengan pembelajaran berbasis flipped learning memiliki kesiapan yang jauh lebih matang, bagaimana menjadi golongan yang pro dengan akad nikah yang dilaksanakan melalui via telepon/ online dan kontra pada hal demikian.

Berdasarkan teori flipped learning, guru berperan sebagai fasilitator, menjembatani para siswa untu berfikir kritis, berfikir yang awal mulanya komplek menjadi abstrak.

\section{KESIMPULAN}

Berdasarkan paparan data dan pembahasan yang telah dilakukan, maka dapat diperoleh kesimpulan bahwa penerapan model pembelajaran flipped classroom di kelas XII IPA 1 MA Bahrul Ulum Blawi tahun pelajaran 2018/2019 terlaksana dengan sangat baik. Hal tersebut ditunjukkan pada persentase tingkat keaktifan siswa pada pembelajaran pertemuan kedua. siswa yang pasif yang ada di deretan bangku belakang juga turut aktif.

Demikian adalah paparan hasil penelitian tentang penerapan model pembelajaran berbasis flipped learning di kelas XII IPA 1 MA Bahrul Ulum Blawi tahun pelajaran 2018/2019

\section{DAFTAR PUSTAKA}

Abdurrahman, Pengantar dan Asas-Asas Hukum Perdata Islam.,

Haryono, Arfiyanti Agustiningrum \& Agung, "Penerapan Model Pembelajaran Flipped Classroom Dan Course Review Horay Berbasis Lesson Study Untuk Meningkatkan Aktivitas Dan Hasil Belajar Siswa Pada Mata Pelajaran Ekonomi di kelas XI IPS 2 MAN Kota Batu, JFE-Vol. 10 No. 22017.

Husniyatus Salamah Zainiyati, 2017. Pengembangan Media Pembelajaran Berbasis ICT, Jakarta: Kencana.

Khalaf, Abd. Wahab, 1972ilm ushul al-fiqh (Jakarta: al-majlis al-a'la Al-Indunisi).

M.Ishom Ahmadi, 2009"Ya Ayyatuha An Nafsu Al Muthmainnah". Yogyakarta: Sj Press.

Munawwir, Ahmad Warson, 1997. Kamus Arab-Indonesia Terlengkap, Surabaya: Pustaka Progresif.

Rusman, dkk, 2013. Pembelajaran Berbasis TIK, Jakarta: Rajawali Pers.

\footnotetext{
${ }^{14}$ Lembar kritik dan saran salah satu siswa kelas XII IPA 1 MA Bahrul Ulum dengan inisial MM.
} 
Very Misbahul Munir, Abdulloh Hamid : Penerapan Flipped Learning Dengan Media Video Pada Fiqih Kelas XII IPA

1 Di MA Bahrul Ulum Blawi

Slameto, 2003. Belajar Dan Faktor-Faktor Yang Mempengaruhinya, Jakarta: Rineka Cipta.

Syah Muhibbin, 2009"Psikologi belajar", (Jakarta: Rajawali Press)

Utami, Sri, Pengaruh Model Pembelajaran Flipped Classroom Tipe Peer Instruction Flipped Terhadap Kemampuan Pemecahan Masalah Matematik siswa; Penelitian Quasi Eksperimen di Kelas XI SMA Negeri 1 Parung), SkripsI. Jakarta: FTK UIN Syarif Hidayatullah. 